\title{
Crescent-in-doughnut sign and telescope sign of intussusception in Peutz-Jeghers syndrome
}

\author{
Akira Hokama, ${ }^{1}$ Tetsu Kinjo, ${ }^{1}$ Kazuto Kishimoto, ${ }^{2}$ Jiro Fujita ${ }^{2}$
}

${ }^{1}$ Department of Endoscopy, University of the Ryukyus, Nishihara, Okinawa, Japan ${ }^{2}$ Department of Infectious, Respiratory, and Digestive Medicine, University of the Ryukyus, Nishihara, Okinawa, Japan

\section{Correspondence to} Professor Akira Hokama hokama-a@med.u-ryukyu.ac.jp

Accepted 29 March 2014
CrossMark

To cite: Hokama A, Kinjo T, Kishimoto K, et al. BMJ Case Rep Published online: [please include Day Month Year] doi:10.1136/bcr-2014204516

\section{DESCRIPTION}

A 26-year-old man presented with postprandial epigastric pain and intermittent haematochezia for 2 months. His medical history consisted of surgery for intussusception due to Peutz-Jeghers syndrome (PJS) at 12 years of age. Physical examination showed pigmentation of the lips and epigastric fullness and tenderness. CT scans disclosed ileoileal intussusception with crescent-in-doughnut sign on cross-section (figure 1). On longitudinal scan of the same lesion, telescope sign of intussusception was shown (figure 2). At laparotomy, an invaginated tumour measuring $4 \mathrm{~cm}$ in diameter was resected surgically from the ileum. Remaining 51 polyps were resected by intraoperative enteroscopic polypectomy. All specimens were hamartoma of PJS. His postoperative course was uneventful.

The intussusception appears differently relative to the slice axis in CT scans and ultrasonography. In the former sign, the crescent is formed by the mesentery enclosing the entering limb of the intussusceptum. ${ }^{12}$ In the latter sign, the proximal bowel (intussusceptum) with a lead point appears to telescope into the adjacent distal bowel (intussuscipiens). ${ }^{3}$ Both the signs are pathognomonic features of intussusception.

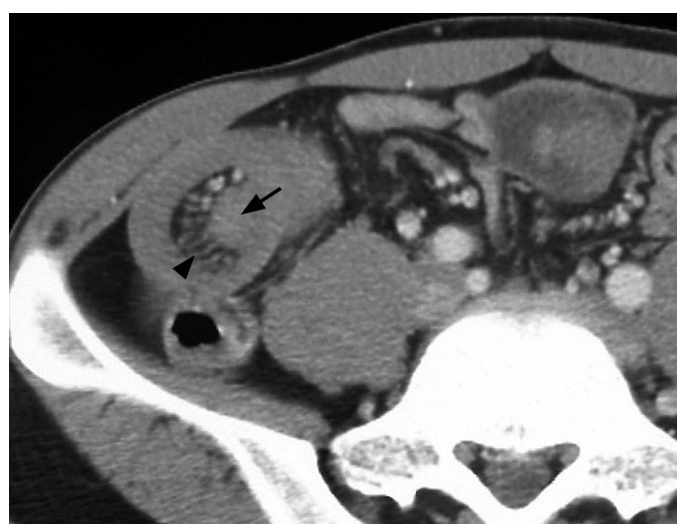

Figure 1 CT scan showing ileoileal intussusception with crescent-in-doughnut sign on cross-sectional view. Note the intussuscepted intestine (intussusceptum; arrow) and the mesentery (arrowhead).

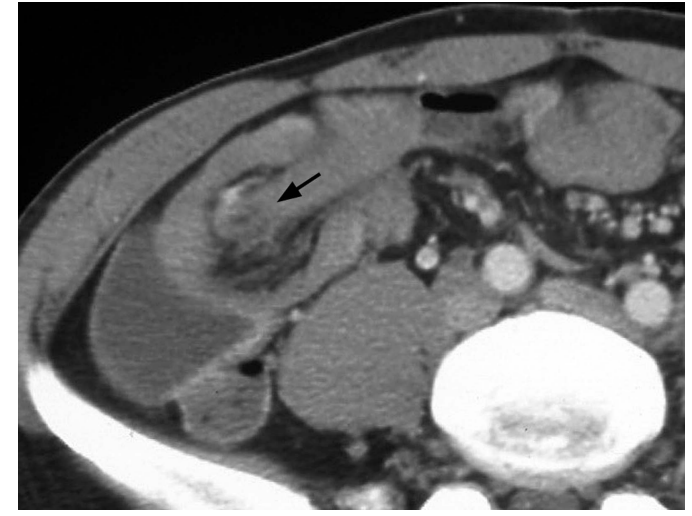

Figure 2 Telescope sign of intussusception is shown on longitudinal scan of the same lesion. Note the intussusceptum (arrow) with a lead point.

\section{Learning points}

Pigmentation of the lips and intussusception are characteristic features of Peutz-Jeghers syndrome.

- The intussusception appears differently relative to the slice axis in CT scans.

Contributors $\mathrm{AH}$, TK and $\mathrm{KK}$ were involved in treatment of the patient. AH wrote the manuscript. JF supervised the study.

Competing interests None.

Patient consent Obtained.

Provenance and peer review Not commissioned; externally peer reviewed.

\section{REFERENCES}

1 Gayer G, Zissin R, Apter S, et al. Pictorial review: adult intussusception—a CT diagnosis. Br J Radiol 2002;75:185-90.

2 Kim YH, Blake MA, Harisinghani MG, et al. Adult intestinal intussusception: CT appearances and identification of a causative lead point. Radiographics 2006;26:733-44.

3 Hokama A, Inamine M, Kishimoto K, et al. Telescope sign of intussusception in Peutz-Jeghers syndrome. Dig Liver Dis 2010;42:153. 
Copyright 2014 BMJ Publishing Group. All rights reserved. For permission to reuse any of this content visit http://group.bmj.com/group/rights-licensing/permissions.

BMJ Case Report Fellows may re-use this article for personal use and teaching without any further permission.

Become a Fellow of BMJ Case Reports today and you can:

- Submit as many cases as you like

- Enjoy fast sympathetic peer review and rapid publication of accepted articles

- Access all the published articles

- Re-use any of the published material for personal use and teaching without further permission

For information on Institutional Fellowships contact consortiasales@bmjgroup.com

Visit casereports.bmj.com for more articles like this and to become a Fellow 